
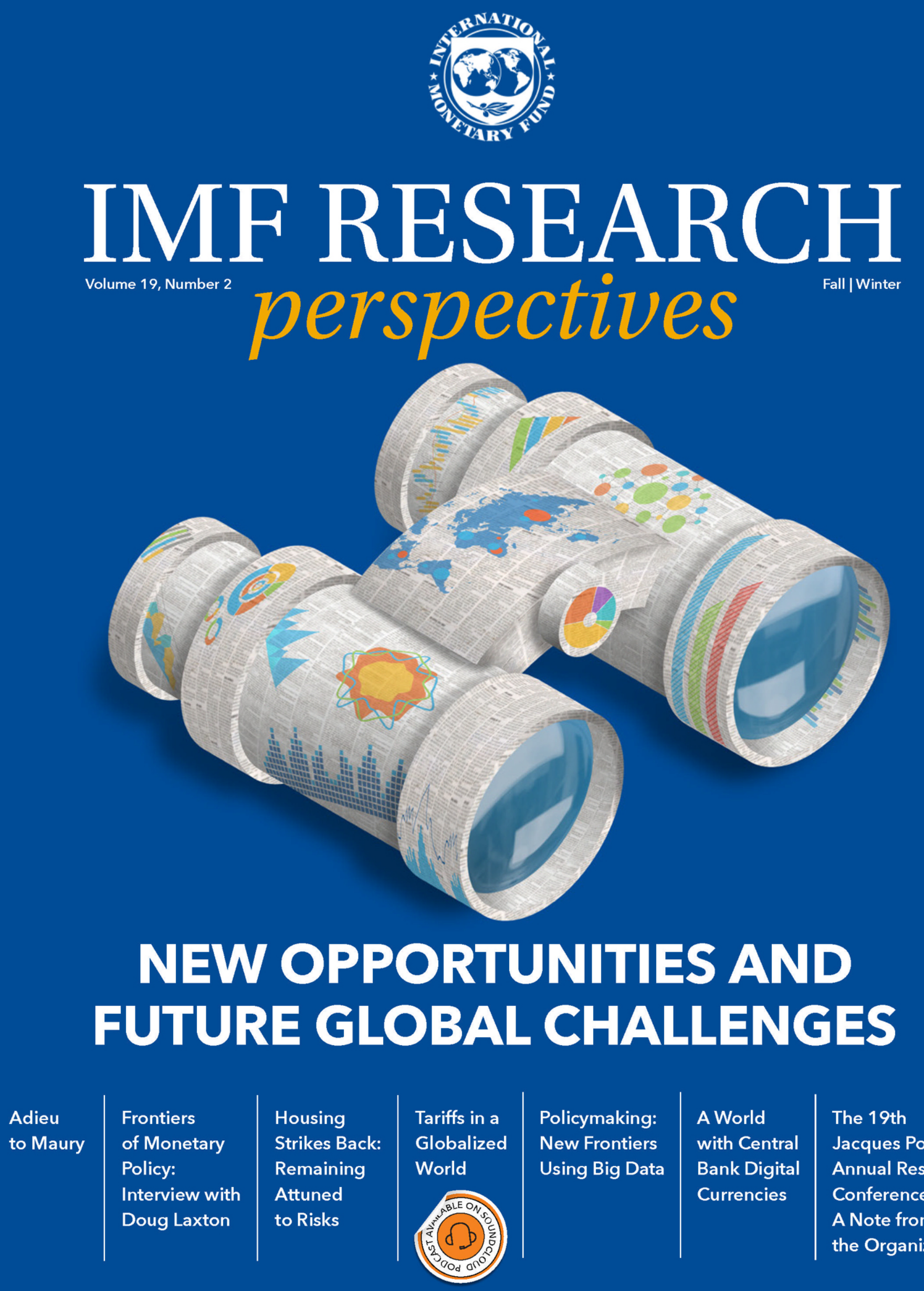

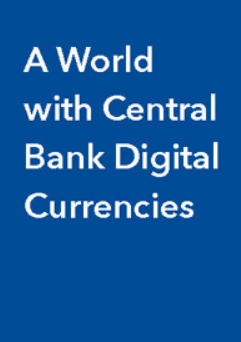

The 19th Jacques Polak Annual Research Conference: A Note from the Organizer 

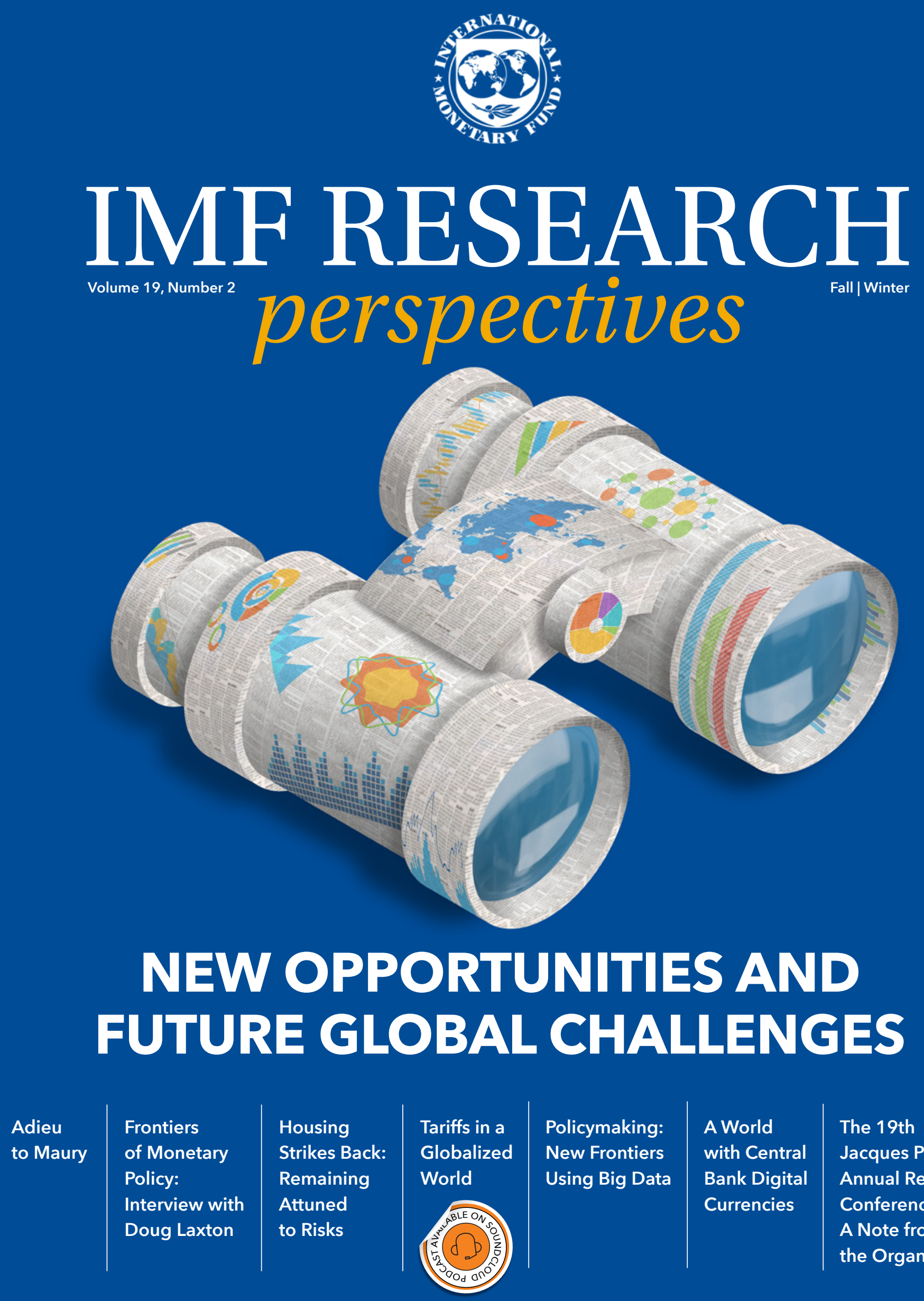

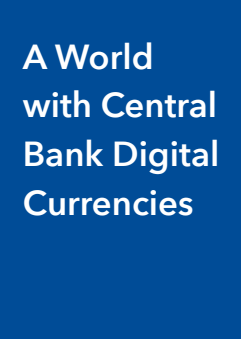

The 19th
Jacques Polak
Annual Research
Conference:
A Note from
the Organizer 


\section{IMF RESEARCH perspectives}

\author{
Editors-in-Chief \\ Deniz Igan \\ Chris Papageorgiou \\ Guest Editor \\ Marika Santoro \\ Assistant Editor \\ Patricia Loo \\ Editorial Assistant \\ Tracey Lookadoo \\ Contributors \\ Anil Ari \\ Emine Boz \\ Lucia Buono \\ Eugenio Cerutti \\ Swarnali Hannan \\ Zoltan Jakab \\ Marika Santoro \\ Cover, design, and layout \\ Creative
}

Corporate Services and Facilities

IMF Research Perspectives-the IMF online bulletin with news on research is a bi-annual publication in English and is available exclusively online free of charge.

The views expressed in the Bulletin are those of the author(s) and do not necessarily represent those of the IMF or IMF policy. Material from this publication may be reprinted with proper attribution.

Editorial correspondence may be addressed to: INTERNATIONAL MONETARY FUND Attn: Editor, IMF Research Perspectives 700 19th Street, NW

Room HQ1-9-253

Washington, DC 20431

USA

E-mail: resbulletin@IMF.org

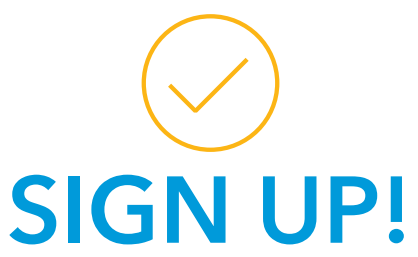

For new issues of the IMF Research Perspectives and a variety of other IMF publication, sign up for an electronic notification at IMF.org/external/cntpst.

Individual issues are available at IMF.org/researchbulletin.

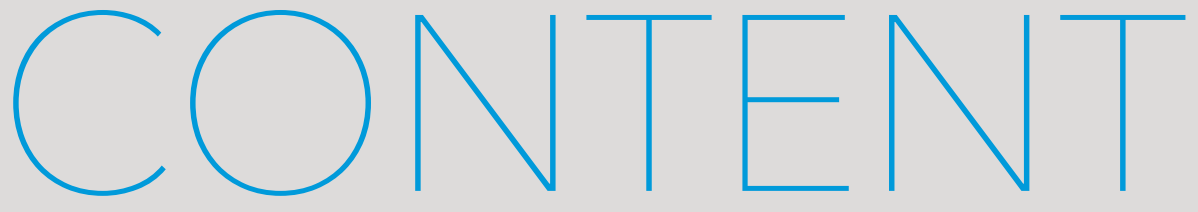

3 Adieu to Maury

5 Frontiers of Monetary Policy: Interview with Doug Laxton on the new book Advancing the Frontiers of Monetary Policy with Tobias Adrian and Maurice Obstfeld

9_Housing Strikes Back: Remaining Attuned to Risks
12 Tariffs in a Globalized World

15 Policymaking: New Frontiers Using Big Data

18 A World with Central Bank Digital Currencies

20 The 19th Jacques Polak Annual Research Conference: A Note from the Organizer

\section{Note from the guest editor}

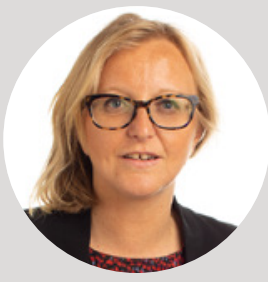

In the Spring/

Summer

2018 issue, we highlighted how the period after the global

financial crisis saw a recovery in housing markets, but also a surge in populism and the revolution brought about by big data. Here, we go one step farther. Future challenges will encompass going from a recovery in the housing sector to a new boom. This would not only pose new threats to macroeconomic and financial stability that central banks will have to tackle, but might also contribute to an even wider gap between young renters and wealthier homeowners.
Populism has spun off into a new wave of protectionism. As technology and the wave of big data advance, so will the economy and policymaking. New policy measures will have to be supported by more complex sets of data with availability beyond traditional official sources and by new communication strategies. The large repository of data available throughout the digitalized domain provides vast, unexplored opportunities for policymaking. And new opportunities and challenges in the digital era can arise with the possible digitalization of money as we know it.

\section{Marika Santoro}




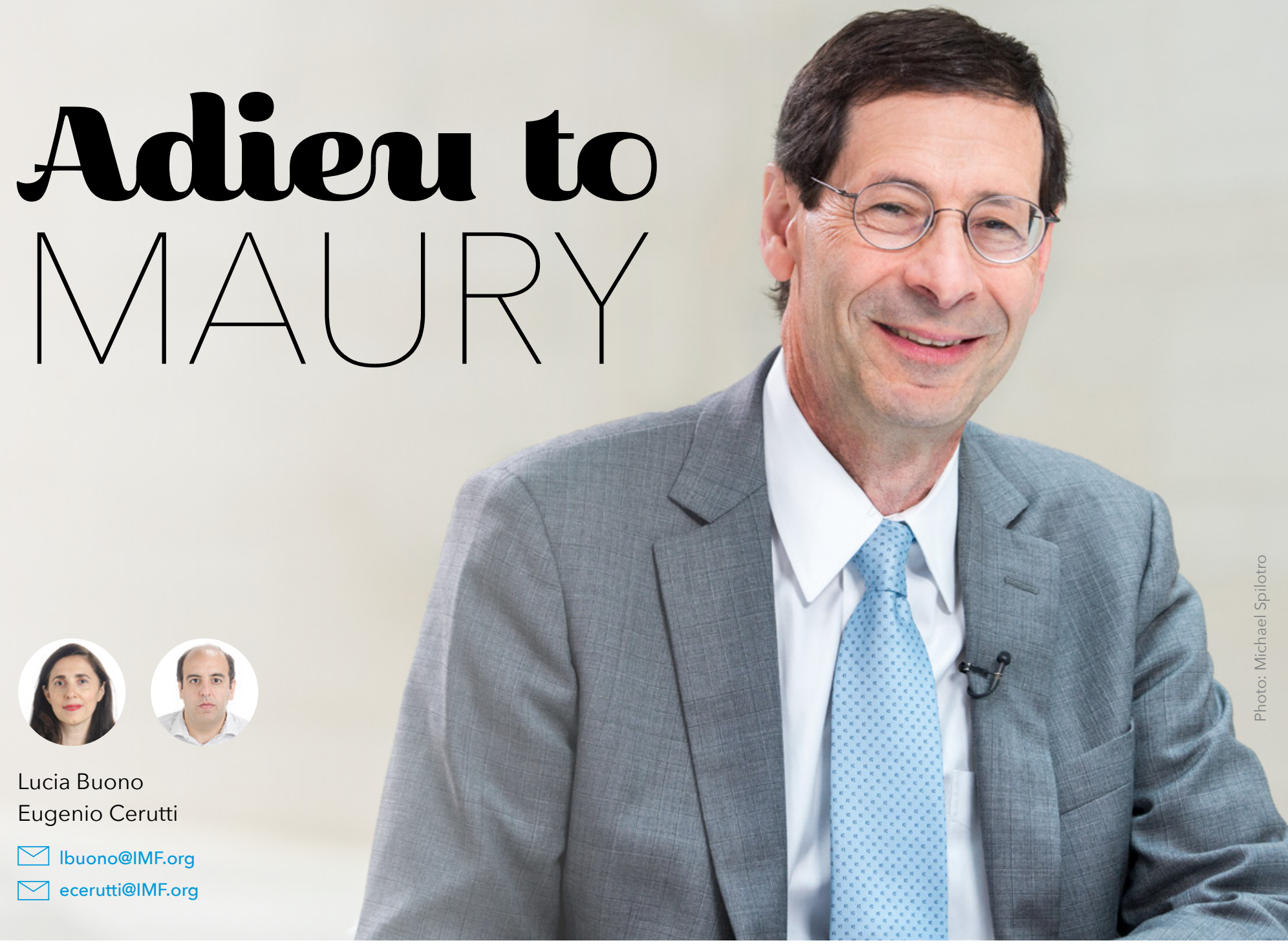

Maurice (Maury) Obstfeld, our chief economist and RES

Director, is retiring at the end of the year after more than three years on the job. His time here has been marked by many achievements, of which this short column can only elucidate a couple, while conveying some of the more personal and intangible aspects that we learned about him and that have influenced IMF staff over his tenure.
As would have been anticipated at the start of Maury's tenure, many of his initiatives were linked to his well-known expertise as an international economist. For example, the External Sector Report (ESR) has seen its methodology renewed and its status lifted to that of an IMF flagship report. The ESR analyzes the current account balances for the world's largest economies. These assessments are a key aspect of the IMF's mandate to promote international monetary cooperation and help countries build and maintain strong economies. Similarly, Maury pushed for further studies on globalization and trade issues. These were reflected in Chapter 2 of the October 2016 World
Economic Outlook, other RES products (including collaboration with World Trade Organization and the World

Bank), as well as in his blogs and opinion pieces calling for more international cooperation and highlighting the danger of some trade policy proposals. As nicely demonstrated in his opinion piece in the Financial Times, "Targeting specific trade deficits is a game of whack-a-mole," he always provided excellent clarity on complex questions using tactful humor to deliver these timely messages.

Maury is not a typical economist who remains within a narrow field. He has a broad range of interests and concerns about the future. One clear example was 
his push to analyze the macroeconomic impact of global warming. Chapter 3 of the October 2017 WEO is part of this initiative. It finds that increases in global temperatures-which have risen at an unprecedented pace over the past 40 years-have uneven macroeconomic effects, with adverse consequences concentrated in countries with relatively hot climates, such as most low-income countries. Maury not only selected this topic, but he also personally disseminated the analysis and its worrisome results around the world in his frequent presentations.

Moving to a more personal perspective on his legacy in RES and the IMF more generally: anybody who has worked at the IMF has experienced an internal review process where suggestions sometimes are delivered in the form of "tracked changes" that are often very extensive, filling the computer screen with mostly red font. Time permitting, Maury's comments were also very extensive, even substantially rewriting most paragraphs. The difference was that his suggestions not only improved the style and grammar, but also were able to both simplify the exposition of ideas, and to link and improve the delivery of the different arguments. This superb level of writing skills and exposition of complicated concepts in simple terms are not surprising when we take into account that he is behind two leading textbooks on international economics-International Economics (with Paul Krugman and Marc Melitz) and Foundations of International Macroeconomics (with Kenneth Rogoff)-which many of us have used to learn international economics. If you benefited from his extensive comments, you should know that he also delivers the same level of insight to his famous coauthors, so do not feel embarrassed!

\section{Another of Maury's qualities that} we greatly benefited from is his outstanding memory. Not only has he always been on top of his agenda and the deliverables, but he knew, after just a few weeks, the names of almost all economists and counterparts, from RES and other departments. He is like a walking library: his broad knowledge of economic literature and ability to point to very useful references are remarkable. His suggestions often involved excellent decades-old articles (sometimes even difficult to retrieve online). This makes us remember that, although no times are exactly the same, each generation bears similarities with those that have come before it-and that those similarities contain a multitude of very valuable lessons.

$\mathrm{He}$ is a strenuous believer in international cooperation. As celebrated by Christine Lagarde at the IMF Annual Meetings 2018 in Indonesia: "The IMF lies at the heart of the new multilateralism that I outlined today. Here, I want to thank in particular our Economic Counsellor, Maury Obstfeld. He has been an intellectual leader, wise advisor, and dear friend. No one is more committed to multilateralism."

\section{Last but definitely not least, Maury's} concerns regarding the health of the planet have a special place for some nonhuman inhabitants as well. He is really a cat person. This was more than evident on a recent trip to Turkey. We wish Maury the best on his return to the West Coast, and hope to continue reading his very insightful writings, as well as viewing cat pictures from his travels around the globe!
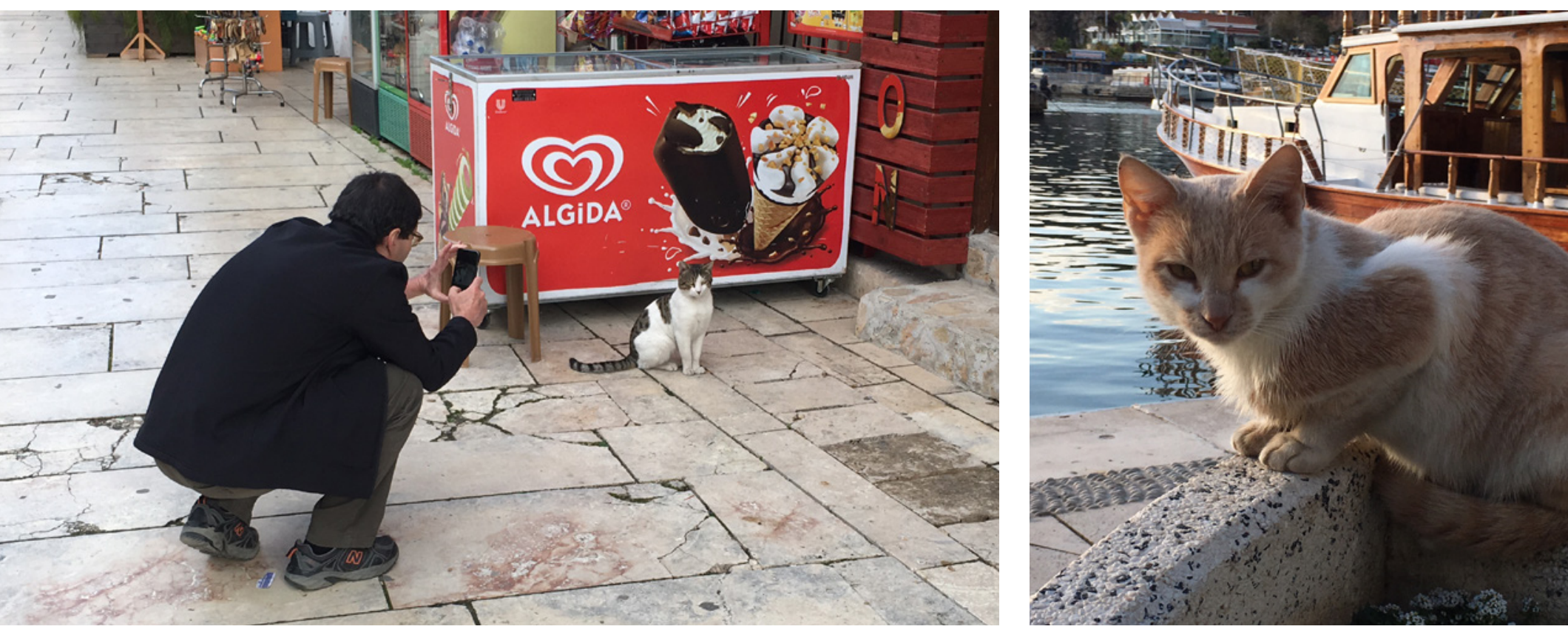


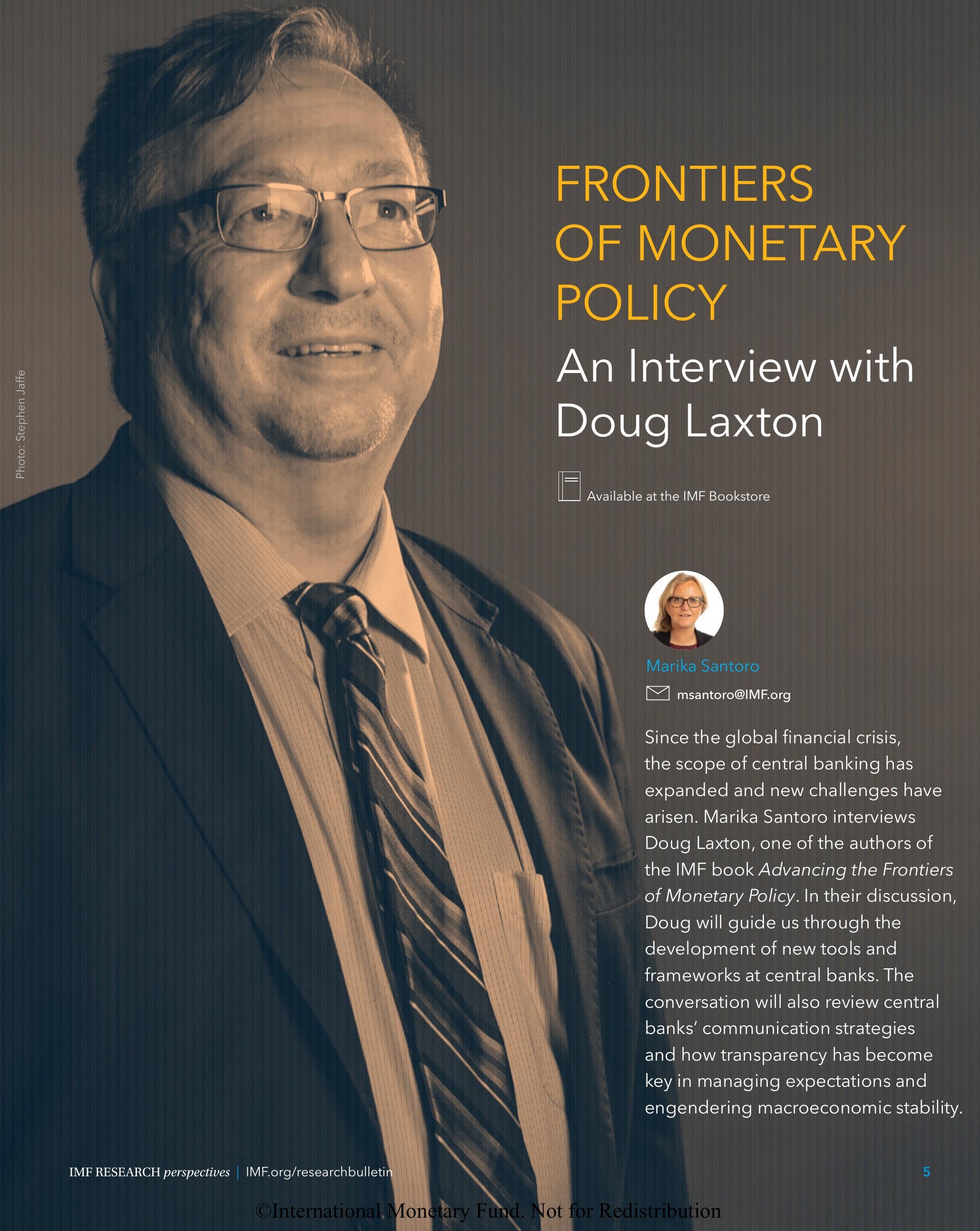




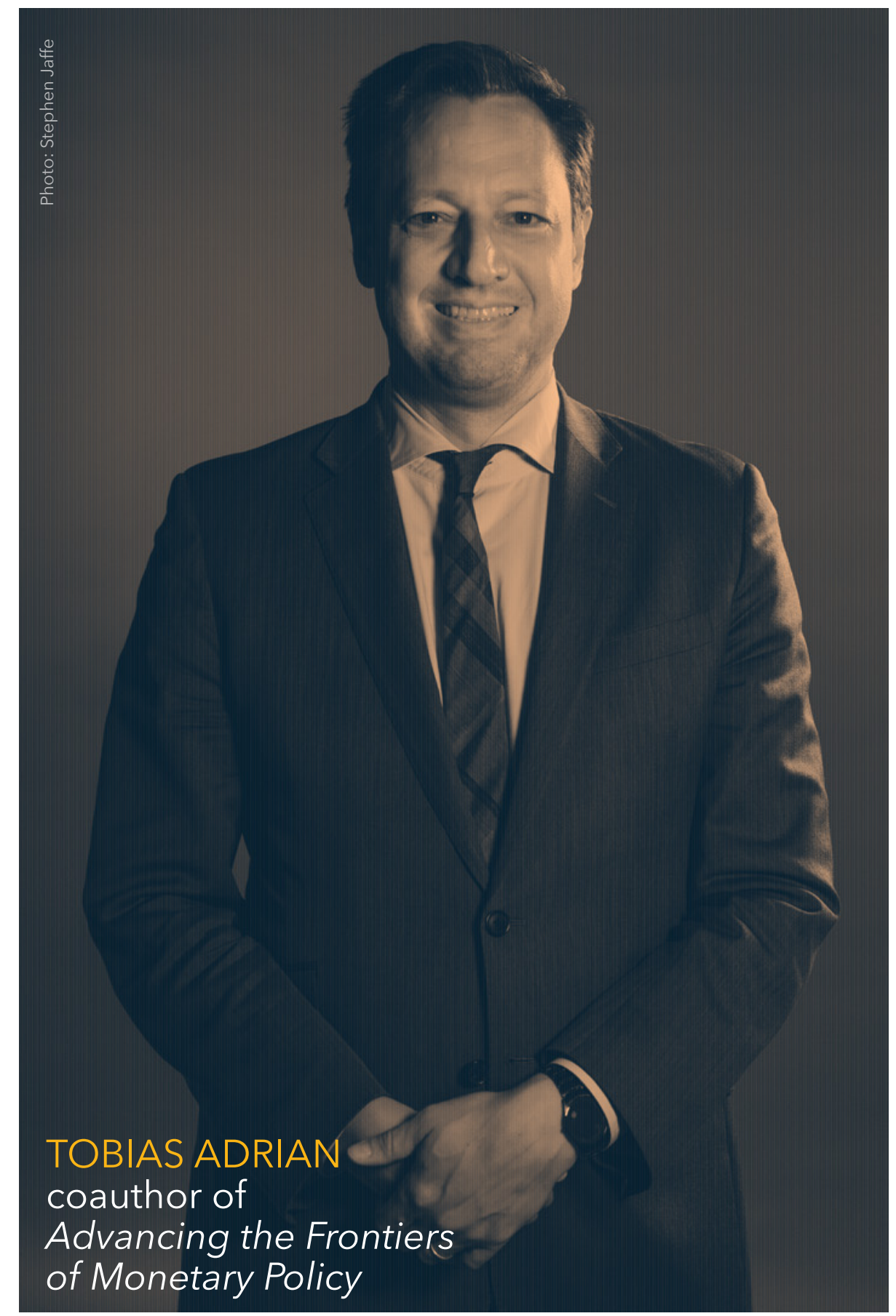

Marika: I am here with Douglas Laxton who, together with Tobias Adrian and Maurice Obstfeld, has come out with a new book on advancing the frontiers of monetary policy. The book highlights state-of-the-art approaches in inflation targeting and has earned outstanding reviews from some very prominent policymakers, including Raghuram Rajan, former governor of the Reserve Bank of India, and Adrian Orr, the current Governor of the Reserve Bank forward-looking monetary policy frameworks. This goes all the way back to New Zealand, which was the very first country to adopt inflation targeting. Let me explain first what inflation targeting is. The label "inflation targeting" is really a misnomer because the approach, as practiced by the best central banks, is not just about targeting inflation. It is also about what central banks can do to contribute to macroeconomic stability. The term "Flexible Inflation Targeting" was used to dispel the misconception that central banks only care about inflation.

Marika: So the book tells us about central bank experiences developing and implementing a Flexible InflationTargeting framework. How difficult is it for a central bank to adopt it?

Doug: Good question. Turns out not so difficult. Many central banks practice Flexible Inflation Targeting. The most transparent and advanced central banks have moved on to the next step, that is "Inflation-Forecast Targeting," and other central banks that have seen the benefits from other country experiences are investing to be able to move in this direction.

Marika: What exactly is InflationForecast Targeting, and what are the benefits?

Doug: Under Inflation-Forecast Targeting, the central bank's inflation forecast is an ideal intermediate target that is used to communicate how the central bank is managing the short-term output/inflation tradeoff. Several central banks that have adopted Inflation-Forecast Targeting have been very successful anchoring long-term inflation expectations at the target and efficiently managing the short-term output/inflation tradeoff. In order to do that, central banks need to have an analytical framework or model where interest rates, output, inflation, and financial conditions are jointly determined. This enables 


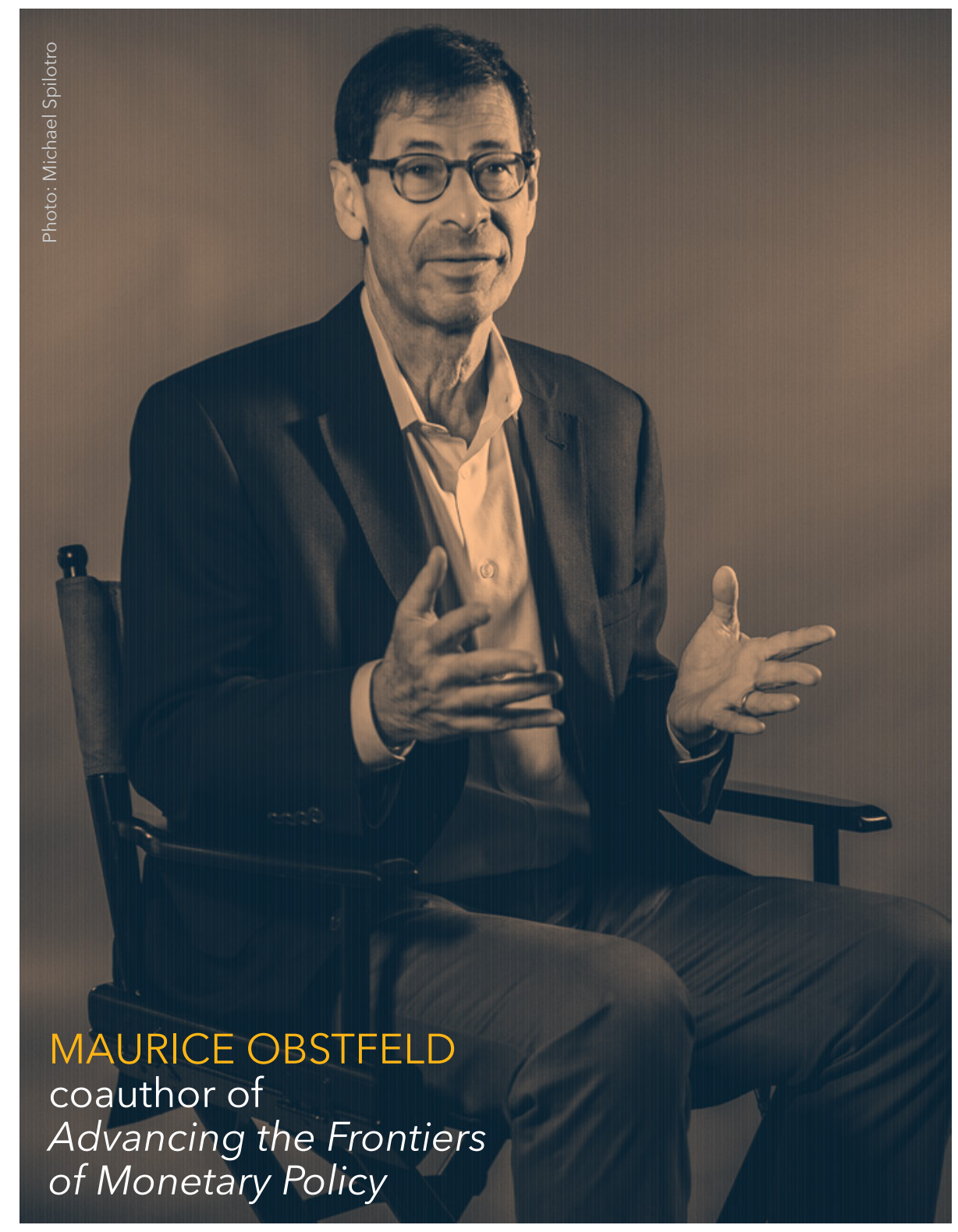

them to forecast not only inflation but also real variables such as GDP and unemployment. Those forecasts, when published with the future path of the policy rate, serve as forward guidance for financial markets to help central banks influence longer-term interest rates and asset prices that matter for households and firms.

Marika: Can you tell us a bit about the history of Inflation-Forecast Targeting?

Doug: In 1990, New Zealand was the first country to adopt inflation targeting. But they lacked an analytical framework to implement a forward- looking approach to monetary policy. Canada was the second country to adopt inflation targeting, in 1991. Unlike New Zealand, they had invested heavily over the years in developing a forwardlooking analytical framework. After Canada started using that approach, New Zealand and other early adopters then borrowed that framework and adapted it to their economies. In fact, some central banks such as the Czech National Bank (CNB) continued to refine the framework and moved right to the top of the transparency ladder.

Marika: You mentioned that InflationForecast Targeting is not just about targeting inflation. How can InflationForecast Targeting help improve macroeconomic stability?

Doug: Many of the countries that adopted Inflation-Forecast Targeting had excessive variability in their economies because long-term inflation expectations were allowed to ratchet upwards. This then required disinflationary episodes such as the Volcker disinflation in the early 1980s. The cost of reducing inflation included significant periods of high unemployment that were necessary to not only reduce inflation but to reanchor long-term inflation expectations at low levels. Effectively, InflationForecast Targeting was successful in helping eliminate the excessive variation in output and unemployment that was a result of inefficient monetary policies.

Marika: You mentioned that the Czech Republic moved right to the top of the transparency ladder. What is the role of communication in this new era of monetary policy transparency?

\section{Doug: Communication is very} important and is covered extensively in the book. For example, the book has a chapter that covers the experiences of the Czech Republic. The CNB adopted a very effective form of communication, what we refer to as conventional forward guidance. Effectively the CNB uses a consistent macroeconomic forecast to help explain the logic of monetary policy decisions. Knowing how the central bank will likely respond to economic shocks helps financial market participants develop their own views about the economy and, more importantly, helps them understand the implications of their views for the expected path of the policy rate. Since 2002, the CNB has been using conventional forward guidance very effectively. Going a step forward, starting in 2008 , they decided to publish the staff's expected path for 
the policy rate. This consistent macroeconomic forecast developed by the staff is used as an important input by the policymakers to explain their own views about the economy and the implications of these views for monetary policy.

Marika: What is the most challenging aspect of central bank communication? Could you give us an example that could serve as a blueprint for future challenges?

Doug: After the global financial crisis, central bank communications were complicated because of the effective lower bound on interest rates. Again, the CNB provides a good example of how a central bank dealt with the problem. The effective lower bound on interest rates represented a challenge, given that most central banks were used to thinking in terms of using interest rates to achieve their inflation and output objectives. In the case of the Czech Republic, a very small open economy whose financial system was not in trouble, the central bank decided that the exchange rate was probably the best instrument in this case. The challenge was to communicate how new policies affecting the exchange rate would help raise inflation to the target. The central bank decided to announce that they were going to depreciate the exchange rate by about 5 percent and that they were prepared to buy unlimited amounts of euro area assets. They explained clearly that they were using the exchange rate as an instrument and were prepared to depreciate further if conditions warranted it. They explained the logic of the depreciation in their inflation reports and, in fact, published forecasts of inflation that showed planned overshooting in inflation from the long-term target.

Marika: Did that strategy work?

Doug: Yes. It was very successful in helping to stimulate the economy and reduce the risk of deflation. Interestingly, when a central bank is implementing such a policy, it actually does not have to buy many assets. Most investors are not going to challenge central banks in such circumstances because they have unlimited ability to purchase assets. The policy is going to be very credible. What is important as a lesson for future challenges is that, even though the Czech Republic ran into the effective lower bound on interest rates, they made it clear that they still had a framework guiding their policymaking, which still involved using instruments to achieve their output and inflation objectives. They were effective in communicating that they were just switching from one instrument to another.

Marika: Are there examples of central banks that used different types of forward guidance?

Doug: There is a chapter in the book that covers the experience of the United States. In 2009, the Fed was facing expectations of the future path of the policy rate that were much higher than what would be consistent with a dual mandate. At that point with very high unemployment and low inflation,

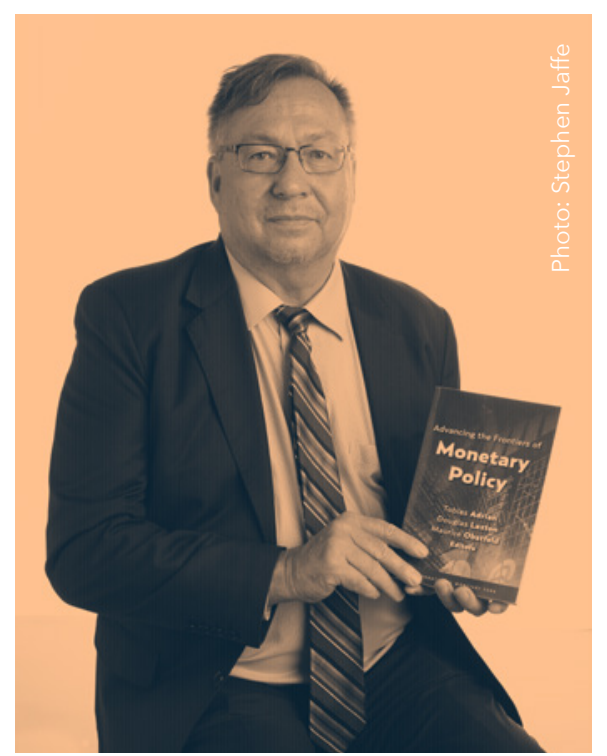

Doug Laxton's book, Advancing the Frontiers of Monetary Policy, is available at the IMF bookstore. the Fed decided to complement its large-scale asset purchases with a new communication strategy, so-called unconventional forward guidance, where it announced its intentions to keep the policy rate low. This strategy, along with the quantitative easing measures, was successful in reducing longer-term interest rates. However, unconventional forward guidance can be problematic when the economy recovers and financial market participants are unsure about when and how the policy might be tightened in the future.

Marika: Is Inflation-Forecast Targeting the end or is there more work that needs to be done?

\section{Doug: Inflation-Forecast Targeting} has been very successful in improving the transparency of monetary policy, anchoring long-term inflation expectations, and managing the short-term output/inflation trade-off. After the financial crisis, central banks have started to also focus more on financial stability issues. Micro- and macroprudential policies seem most appropriate for mitigating the risk of a financial crisis. These policies are designed to target risk at their source with minimal distortions on other sectors and to strengthen the resilience of the financial system to potential shocks. However, the effectiveness of macroprudential policy is not yet firmly established, though early evidence seems promising. And the ultimate effectiveness of such policies could suffer from inaction bias, implementation lags, and a scope that is too narrow to affect newly emerging risks. As a priority, prudential policies, both micro and macro, should be designed and improved to overcome, or at least minimize, these hurdles. The book highlights how the IMF, as well as other institutions, is working to develop analytical frameworks to support macroprudential policy analysis. 


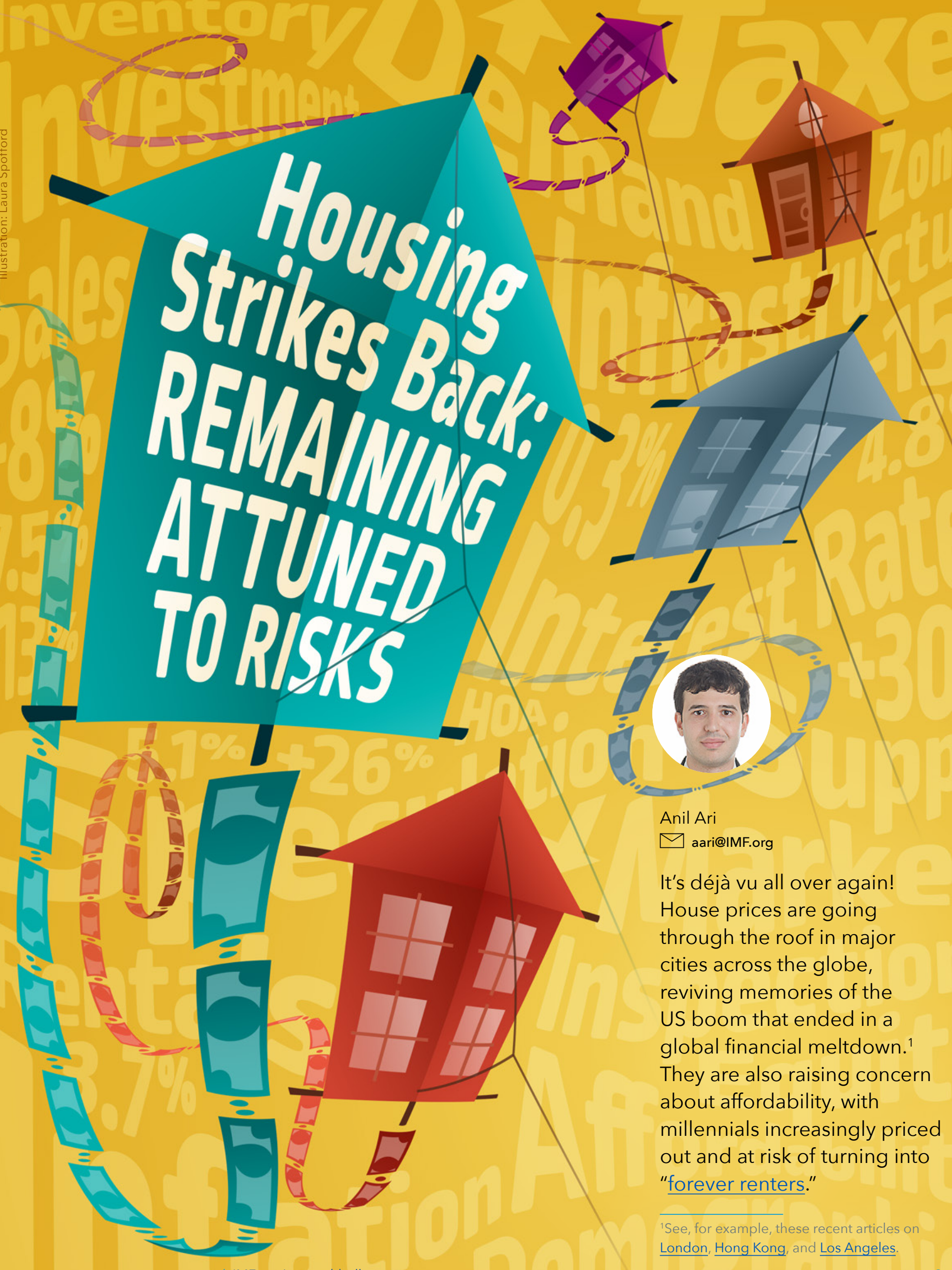

IMF RESEARCH perspectives | IMF.org/researchbulletin 
Housing serves a dual purpose: it is a residential good for occupants but at the same time an attractive asset for occupants and investors alike. It is often, but not exclusively, the latter of these that makes housing markets susceptible to booms and busts. While housing is local, drivers of house price booms do not have to be (especially in a financialized and globalized world): sometimes booms are driven by speculative demand from domestic buyers, other times housing in one country might become a destination for capital inflows from abroad.
A forthcoming IMF working paper studies the role of foreign buyers. The work is founded on the idea that political uncertainty in emerging markets may drive wealthy people from these countries to invest in real estate in developed economies as a safe haven for their wealth, as some Chinese investors do in Vancouver and some Middle Eastern investors do in London. "Foreign buyers may concentrate their house purchases in areas where a large number of people originating from their homeland reside," according to Yu Shi, one of the authors of the study. "This could be in anticipation of possible future migration or because information asymmetries are mitigated through communication within the diaspora." The availability of granular house price and demographic data allows the authors to test this hypothesis in US housing markets. They find that, when political uncertainty rises in an emerging market, house prices increase more in areas where a relatively large share of residents were born in the emerging market country in question.

Figure 1: Real house prices in selected cities $(01-2000=100)$

$2000-2006(2000=100)$

200

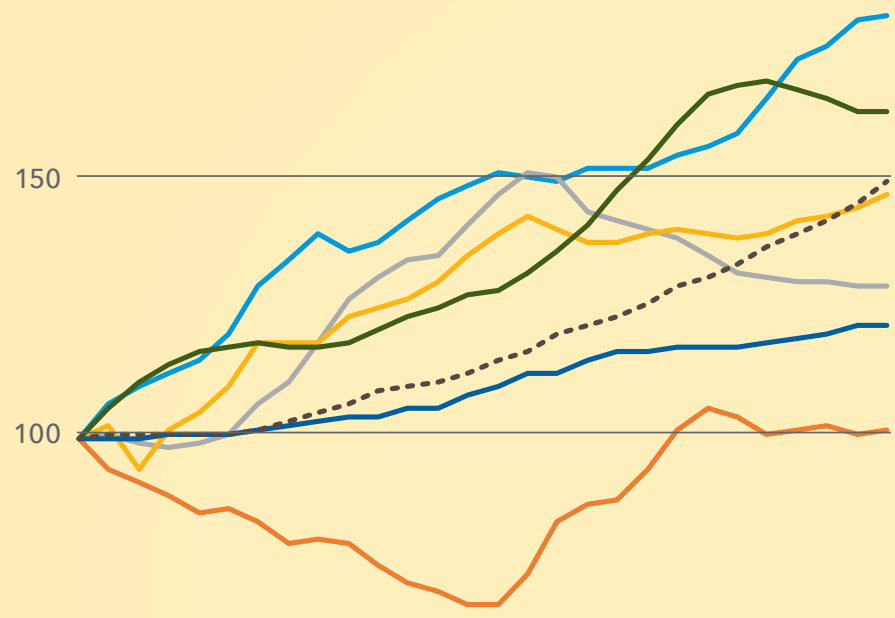

50
$2011-2018(2011=100)$

200

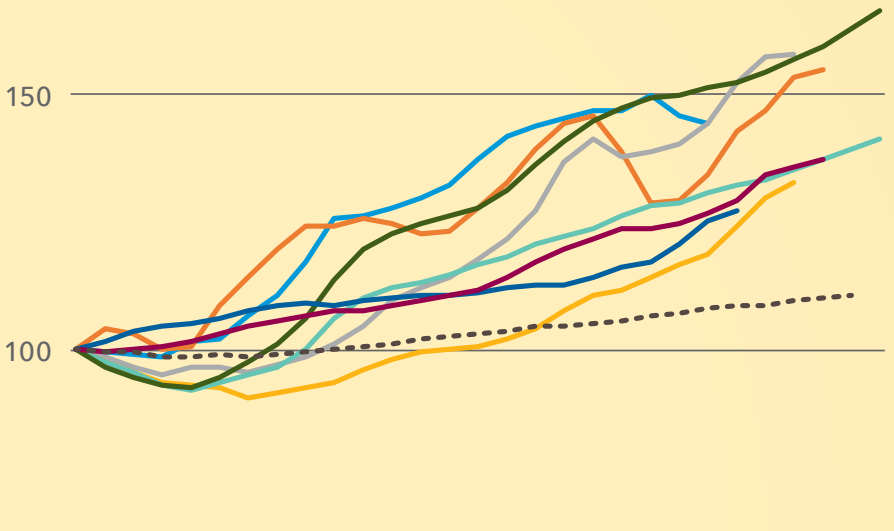

50

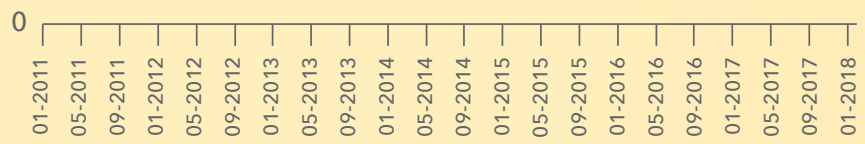

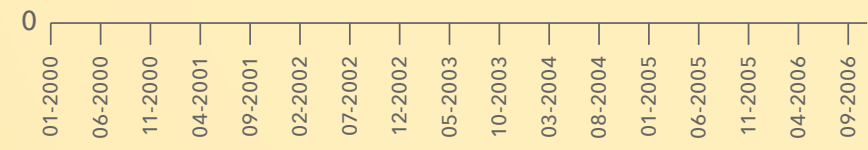


...when political

uncertainty rises in

an emerging market,

house prices increase

more in areas where a

relatively large share of

residents were born in

the emerging market

country in question.

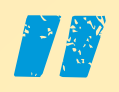

This study is an example of broader developments in the IMF's analysis on housing markets over the past decade. "You will see that the IMF's analysis has adapted as housing markets have become more 'globalized' and developments at the subnational level have gained greater prominence" says Hites Ahir, one of the authors of a forthcoming chapter on IMF surveillance and policy advice. Worldwide aggregate trends are regularly summarized in the Global Housing Watch, and cross-country assessments of real estate vulnerabilities are a regular part of the Early Warning Exercise, while country reports provide more detailed coverage of macro-relevant housing market developments at a more granular level. Chapter 3 of the April 2018 Global Financial Stability Report documented rising synchronization of house prices around the world and showed that countries' and cities' exposure to global financial conditions may explain this trend.

Ongoing work aims to continue to improve the understanding of what drives real estate market developments, and what policymakers can do about them. For instance, IMF economist Michal Andrle, together with Miroslav Plašil from the Czech National Bank, is building a toolbox that contains two indicators: house prices implied by the borrowing capacity of households, and those that correspond to a "fair value" derived from the net present value of rental income. These improve upon simple price-to-income or price-to-rent indicators by bringing on board current and expected dynamics of income and interest rates. "Our approach is forwardlooking, reflects the specifics of mortgage plans and national tax structures, and does not need historical data for estimation," says Andrle. That is not to say that history cannot be helpful: A forthcoming IMF paper uses a general equilibrium model to reach the conclusion that house price rises in the US during the 2000s can largely be explained by an increase in fundamental housing demand.

This increase could be driven by easier access to mortgage financing, and the expectation that the underlying shock is persistent.
"By having a model which can match historical data features on land and structure prices and quantities, we can learn a great deal about drivers of house prices," says Weicheng Lian, the author of the paper.

Policymakers (and millennials) might wonder: What can policy interventions achieve? The experience of Hong Kong $\mathrm{SAR}$ is instructive. Following a steep rise in house prices over the past decade, authorities tightened macroprudential regulations on residential mortgages and raised stamp duty taxes on house purchases, including those aimed exclusively at foreign buyers.

A recent IMF working paper by Pau Rabanal uses a macroeconomic model with a housing sector to demonstrate that, without these policies, house prices would have been approximately 10 percent higher. "Stamp duty taxes are helpful in slowing down house price appreciation, especially for fixed-exchange-rate-regime economies," says Rabanal. "But treating residents and nonresidents differently can be controversial because, in that case, stamp duty taxes are considered as capital flow management measures." Increased vigilance-guided and supported by research-remains key to preventing the present conjuncture in global housing markets from becoming a sequel to what happened in the run-up to the global financial crisis. 
The last time there were tariffs in a meaningful way-and we have to go back really far, to the post-World War II eraglobal exports were around 5 percent of global GDP, a far cry from more than 20 percent of global GDP in 2017. ${ }^{1}$ With the advent of trade liberalization and globalization, tariffs were becoming a relic of the past. Not anymore!

How do economists deal with tariffs in a globalized world? Truth be told, economists are not huge tariff fans. At first blush, the pushback seems counterintuitive. If a country imposes tariffs, imported goods become more expensive, inducing consumers to switch to domestic products. Domestic production increases, imports decrease, and exports increase-leading to a decline in the current account deficit and an increase in domestic production.

However, in a world with crossborder production chains, product diversification, flexible exchange rates, and possible retaliation by other countries, the resulting impact of tariffs is far more elusive, depending upon the relative effect of a host of intricate factors.

\section{Consider the dilemma of a car} buyer in the US in a world where tariffs are imposed on all products, including cars and auto inputs. The choice is not between the cheaper Ford versus the tariff-induced more expensive Volkswagen. If the inputs used to produce the car (such as tires, aluminum, and rubber) are subject to tariffs, the cost of producing the domestic car would increase and might be transmitted to the buyer. The choice then becomes between the expensive Ford versus the expensive Volkswagen -whichever you choose, your wallet will be hurt. Similarly, the domestic car producer does not get a free pass.

1 Data sources: IMF, Direction of Trade, World Economic Outlook.
The increase in the cost of production could affect the volume of sales, both in the domestic and international markets.

Now multiply the car buyer-seller dilemma by all the products used within an economy. Furthermore, lower imports due to the tariff could be offset by an appreciation of the currency to achieve the external balance, leading to an overall contraction in exports, consumption, investment, and output.

A recent study takes a holistic view of the macroeconomic consequences of tariffs using data on 151 countries over the period 1963-2014. "Tariff increases lead to significant declines in domestic output and productivity in the medium term," Davide Furceri, a senior economist in the IMF's Research Department, says. "In addition, tariff increases result in more unemployment, higher inequality, and real exchange rate appreciation. There are only small effects on the trade balance."

Professor Andrew K. Rose (University of California, Berkeley) highlights some of the interesting asymmetric effects found in the study: "The medium-term decline in output is higher if the tariff increase occurs during an economic expansion. Tariff increases also have more adverse effects for advanced economies than for poorer countries. Finally, the mediumterm output effects associated with a tariff increase are not symmetric to those that follow tariff reduction."

Jonathan D. Ostry, Deputy Director in the IMF's Research Department, concludes: "Overall, our results suggest that tariff increases have adverse domestic macroeconomic and distributional consequences. Our results support the case for free trade and are in line with conventional wisdom."

The title of a blog by Maurice Obstfeldthe IMF's Economic Counsellor and

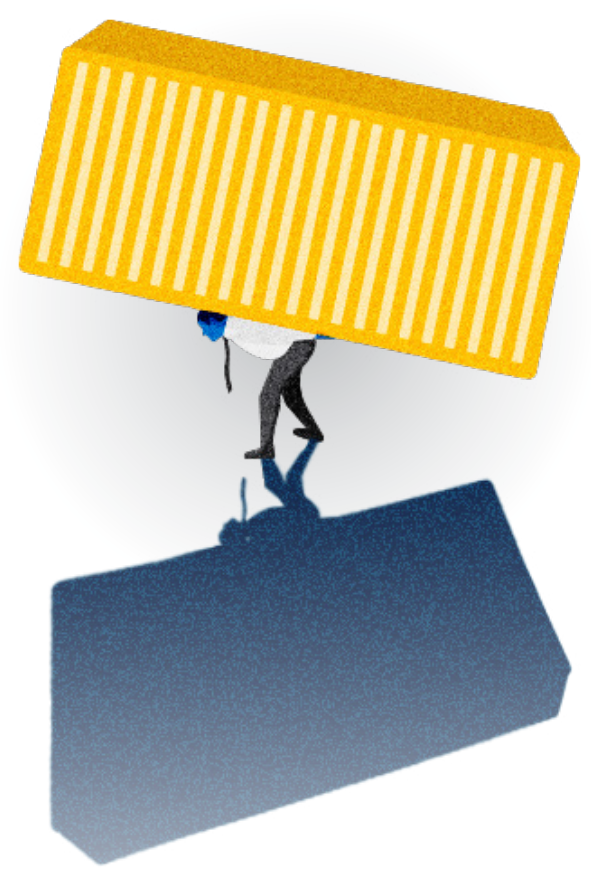

Director of the Research Departmentsummarizes it all: "Tariffs Do More Harm than Good at Home."

Similarly, the IMF G-20 surveillance note cautions that the imposition of tariffs by the United States and potential retaliatory measures by its trading partners could have significant costs for the global economy-reducing growth and investment, disrupting global supply chains, and hurting consumers. The IMF's recent External Sector Report advises countries to avoid protectionist policies as they can have significant adverse effects on domestic and global growth, but have a limited impact on external imbalances.

Is this the first time since World War II that there are signs of rising trade protectionism? In his recent book Straight Talk on Trade, Harvard University economist Dani Rodrik draws the analogy of the trade protectionism chatter of the early 1980s, owing to stagflation in the advanced economies. Eventually, the world witnessed unprecedented expansion of global trade in the subsequent decades. Let's not acquiesce to public transport just yet. 

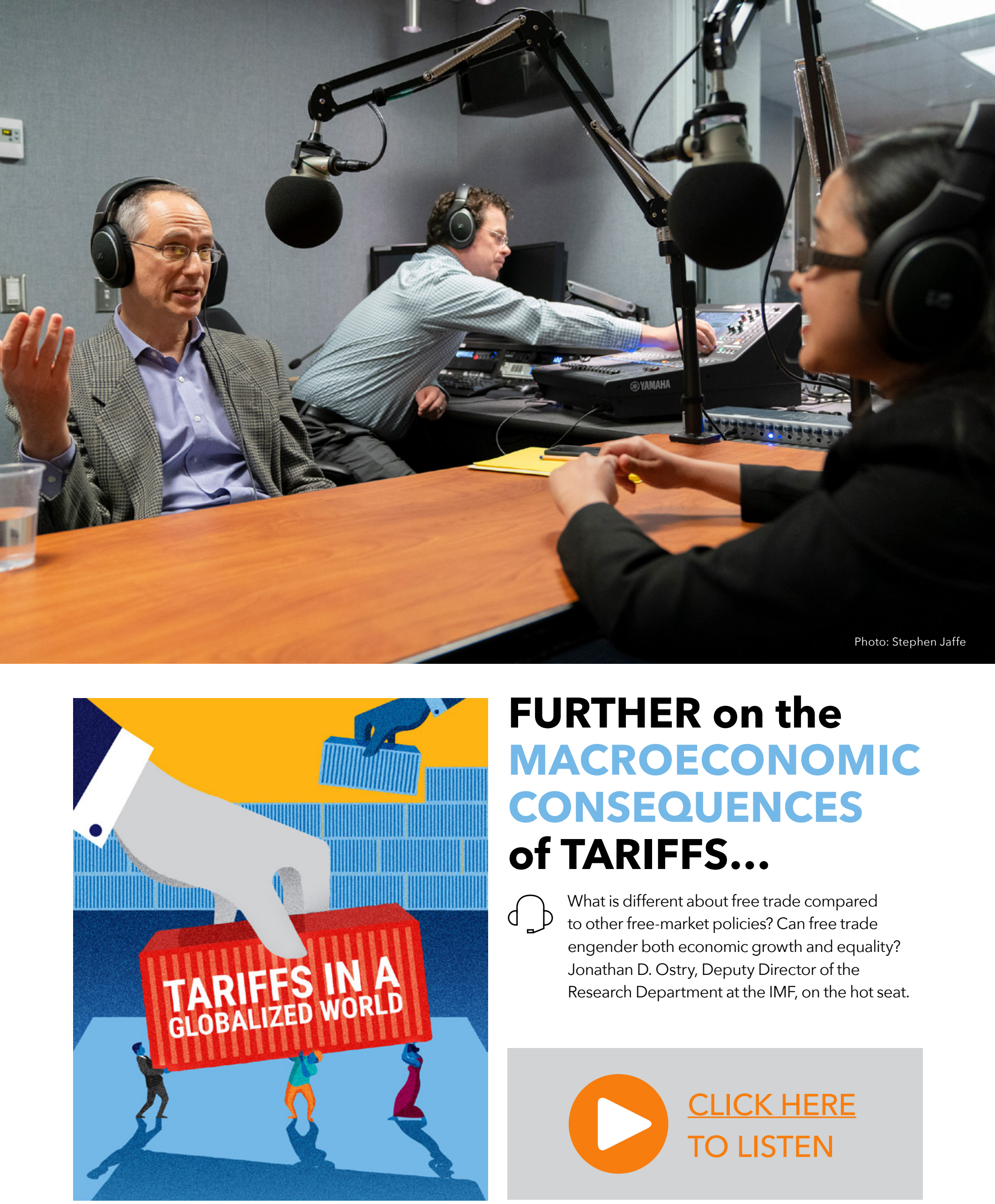

\section{FURTHER on the} MACROECONOMIC CONSEQUENCES

\section{of TARIFFS...}

$\int \begin{aligned} & \text { What is different about free trade compared } \\ & \text { to other free-market policies? Can free trade }\end{aligned}$ engender both economic growth and equality? Jonathan D. Ostry, Deputy Director of the Research Department at the IMF, on the hot seat.

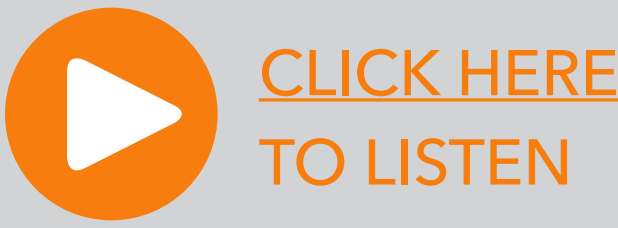



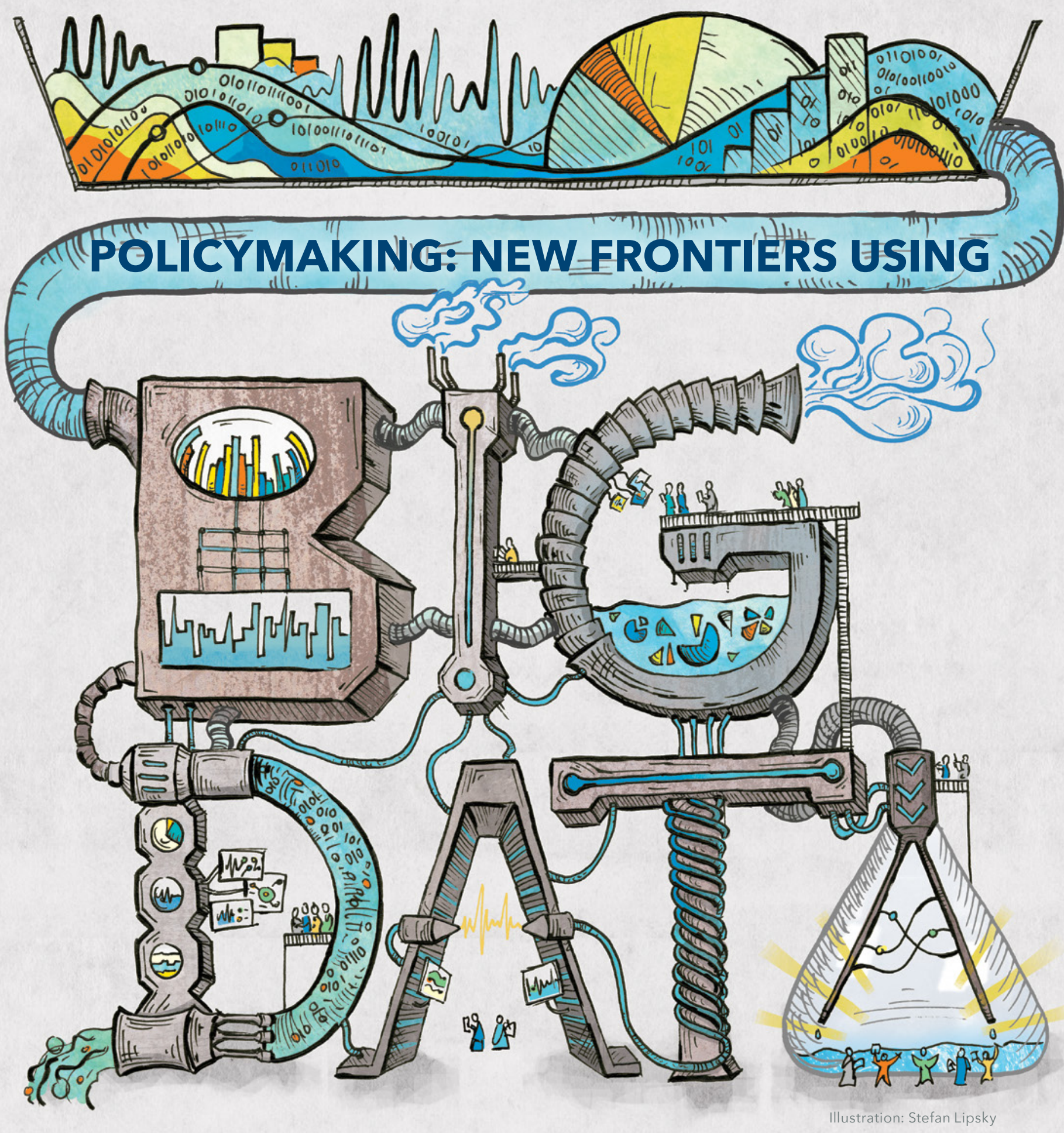

In our previous issue, we flashed how the wave of big data has been a game changer in the past decade and what new avenues it can open for the field of economics. More important (if you are a policymaker), the large pool of information available digitally can provide new tools to guide and support policy decisions. The capability to produce new indicators, tackle official data time lags, and support forecasting can be vital for increasing the speed of inception and implementation in policymaking. A wide array of projects at the IMF has recently aimed

Marika Santoro to explore the potential in this area. 
Cross-country policy analysis is a valuable input for policymakers. Often a country does not have a big enough sample size or sufficient variation in its historical policies to adequately assess the effects of a policy change under consideration. Having detailed information on similar measures adopted by other countries could help by providing a deeper understanding of the main effects to be expected, but such information may not be available from standard data sources. One such example is tax policy. It is very cumbersome to obtain comprehensive information on the major tax policy changes in different countries using official data sources. However, news reports can be an excellent source for such information. The challenge then is to transform that information into useful data. Applying new text-mining techniques to 37,000 tax-related news items, a team in the IMF Fiscal Affairs Department (FAD) has built a new, comprehensive database of tax policy measures adopted in 23 advanced and emerging market economies over the past four decades-the Tax Policy Reform Database (TPRD). The TPRD contains more granular information on tax policy actions compared with existing traditional databases. The innovation of the TPRD lies in the systematic documentation of the direction of changes in rates and tax bases for six different tax types, the exact announcement and implementation dates of tax measures (for example, day and/or month and year), whether the measures represented major tax changes (such as tax reforms), and whether they were phased in over multiple years.
Similar gains in terms of more detailed and, in some cases more timely, information could be achieved in other areas of fiscal policy. Many countries are consolidating their government banking arrangements and implementing information technology systems designed to automate the management of public finances. These innovations in digitalization of government payments and accounting systems mean that real-time daily fiscal data are becoming available. However, these data remain heavily underutilized. Florian Misch, an economist in the IMF's FAD, says: "Trends in daily tax data can mirror a large array of macroeconomic

\section{It:}

\section{Trends in daily tax data}

\section{can mirror a large array \\ of macroeconomic}

developments in real

\section{time, and can be used}

to enhance and upgrade

fiscal surveillance

and monitor real

economic activity. developments in real

time, and can be used

to enhance and upgrade

fiscal surveillance and monitor

real economic activity." Ongoing

projects in FAD aim to make the use of such data more operational, with a focus on automatic data transmission and processing to extract the indicators of interest.

Timely statistics on trade flows would also be very valuable, as they can be used to estimate key real activity indicators or fiscal revenues. However, for many countries, the only source of such data is the official national accounts statistics, which suffer from considerable time lags. Ongoing research in the IMF Statistics Department (STA) uses big data on vessel traffic from the Automatic Identification System (AIS) to measure trade activity for small island states.

"AIS data could allow statistical agencies to supplement existing data sources on trade. These data are more granular (port by port) and more timely than official customs data, which are often only available after long delays, especially for developing countries," says Serkan Arslanalp, from the STA team. The authors take Malta as a benchmark case to demonstrate that AIS-based indicators match official maritime statistics collected by Eurostat and can provide proxy indicators about current trends in trade.

Applications of big data to financial surveillance have also started to emerge. Using text-mining techniques to capture the tonality of articles published around the world between 1991 and 2015, a group of economists in the IMF's Research Department (RES) 
have constructed a daily newsbased sentiment index for both advanced economies and emerging markets [https://cepr.org/active/ publications/discussion_papers/ dp.php?dpno=13366]. They then asked whether optimism (or pessimism) in today's news can help predict future changes in asset prices. Changes in the news-sentiment index they created have a significant impact on asset prices in the short term, suggesting that the index is a very good proxy for investor sentiment. Interestingly, they also find that foreign news has a stronger impact on asset prices than local news. In fact, the general mood captured in the news published around the world every daythe global news sentiment-turns out to be a better predictor of changes in local asset prices than other typical measures of global risk aversion, such as the VIX. Damien Puy, one of the economists working on the project in the IMF RES, says, "Although we are still in the process of understanding why news sentiment matters, the project already shows that monitoring news sentiment in real time is a very effective way to capture sudden changes in investor sentiment, which is key to our financial surveillance job."

Everything we've mentioned here points to opportunities for countries to set up engines to usefully collect and decipher data available in the digital domain. The IMF hosted a series of events during the Spring Meetings in April 2018 in Washington, DC on a similar theme of using digital data to support and complement official statistics to create databases to benefit better policymaking. [https://www.imfconnect. org/content/imf/en/annual-meetings/ calendar/open/2018/04/18/big_data_ and_economicslessonsfromthefrontier =126325.html]. The key challenge is to set up flexible bodies and proper procedures that can handle large data flows and transform them in a timely manner into accessible data. In an increasingly fast-paced world, policymaking nowadays is even more about timely decisions. Big data is the way to go!

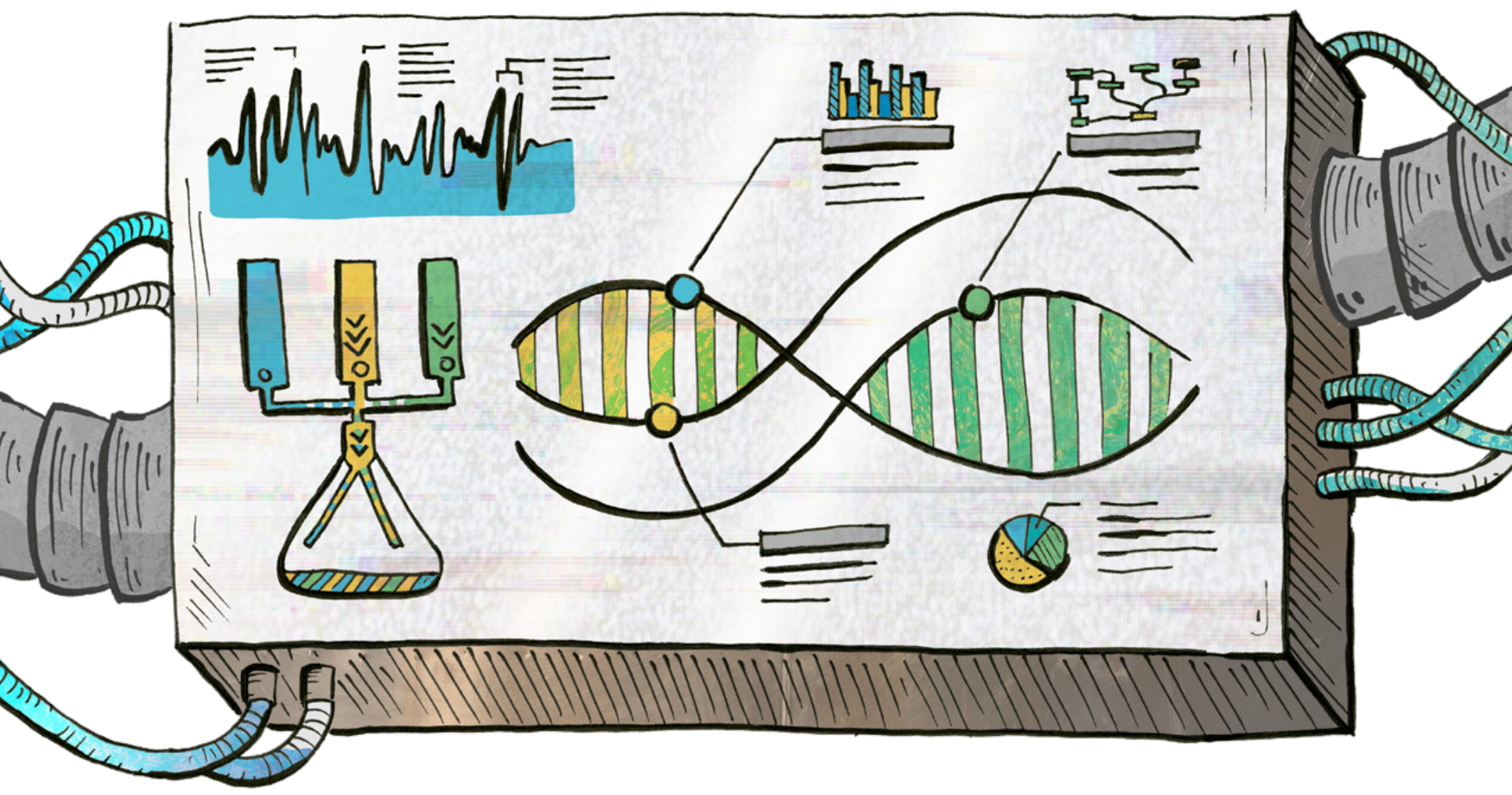




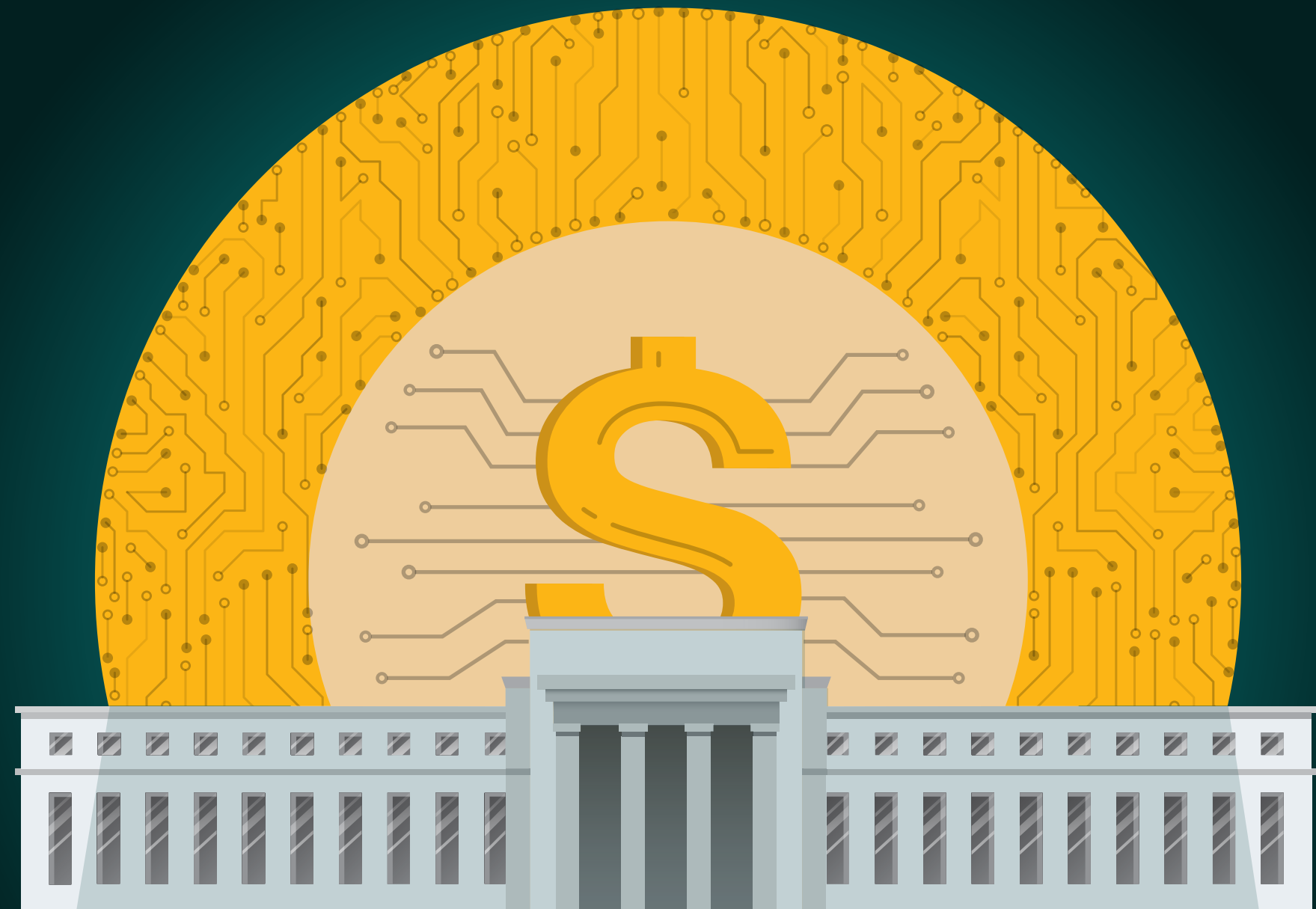

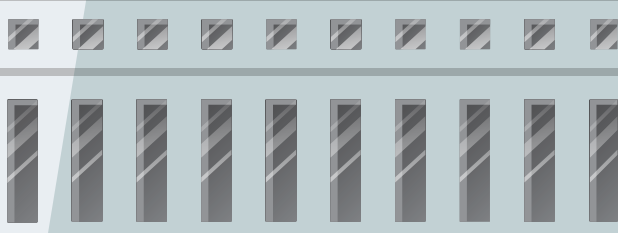

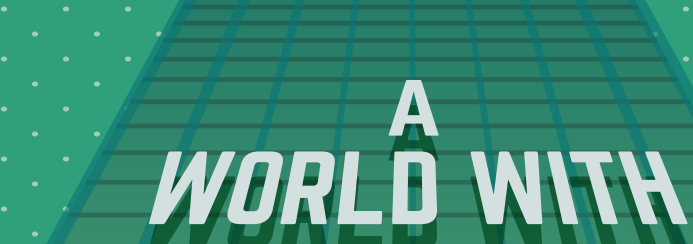
BENTAAL BALK D] 61 GIDREIEL -IMF RESEARCH perspectives | IMF.org/researchbulletin 
Every day, it seems, brings a new privately issued digital (and crypto) currency. These may not be alone for much longer. Central banks are considering issuing their own digital currency, or CBDC. CBDC seems a natural next step in the evolution of official coinage (from metal-based money, to metal-backed banknotes, to physical fiat money). A recent study by a group of IMF economists considers how life would change, if at all, in a world with CBDC.

While banks have been using digital forms of payment for interbank transactions and settlement for quite some time, CBDC would entail a digital form of fiat money that could serve as legal tender for transactions by the public at large. Like its physical equivalent-cash-CBDC would satisfy the traditional functions of money: a unit of account, a means of payment, and a store of value.

But would there be any demand for $\mathrm{CBDC}$, and why might central banks wish to dust off their payment systems to introduce something new? Users may not necessarily swarm to CBDC, at least not in all countries. Payments in commercial bank deposits are becoming increasingly efficient and user-friendly, as banks partner with tech companies such as Apple, and central banks roll out improved backend systems to clear retail transactions. Even in lower-income countries, private sector initiatives such as the mobilephone-based money transfer system, M-Pesa, are facilitating transactions. Nevertheless, in countries with underdeveloped payment systems, there may well be demand for CBDC. And CBDC allowing for anonymous small-value transactions may one

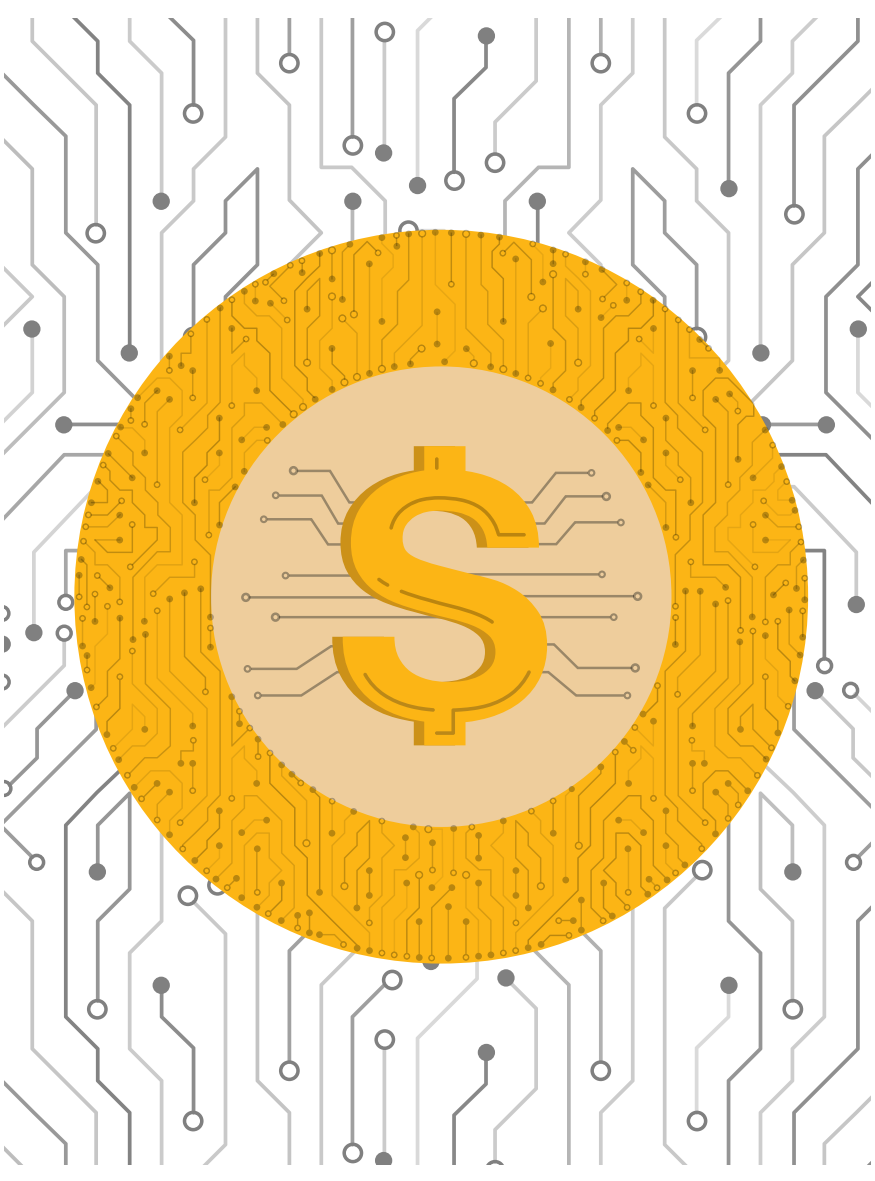

day replace cash, which will seem increasingly anachronistic as our lives become more digital.

Why might central banks consider introducing a digital currency? One reason is to encourage financial inclusion. CBDC could reduce costs to access money and related services by those not part of the banking system and by inhabitants of remote areas. Another reason is to reduce costs associated with cash. ${ }^{1}$ Some also believe that a palatable alternative to private forms of money is essential for healthy competition-to keep prices low and quality high.

And if cash were to eventually disappear, an interest-bearing CBDC could help sustain policies of interest rates below zero. ${ }^{2}$ Severe recessions

1 Box 1.4 https://www.IMF.org/en/ Publications/GFSR/Issues/2018/04/02/ Global-Financial-Stability-Report-April-2018 2 See Assenmacher and Krogstrup (2018) "Monetary Policy with Negative Interest Rates: could be easier to fight without relying on unconventional monetary policies (such as quantitative easing and forward guidance).

What could be the risks associated with $\mathrm{CBDC}$ that might make central banks reluctant to introduce it?

The design of $\mathrm{CBDC}$ in terms of anonymity (traceability of transactions), security, transaction limits, and interest earned will largely determine its risks. A CBDC design that mimics the features of bank deposits could divert funds from banks and increase their cost of funding and, consequently, the cost of financing for borrowers. Also, the adoption of a CBDC could facilitate runs from the banking system during periods of financial stress.

However, the potential costs and risks can be contained through design choices and policies. For example, a central bank could limit the risk of deposit flight by setting limits on individual CBDC holdings. In addition, during episodes of runs, a central bank could lend the funds it collects from deposits back to banks, and more easily service withdrawal requests from bank clients.

CBDCs may become a reality soon. IMF research suggests that its popularity and impact will largely depend on its design features and, while risks exist, policies can be introduced to mitigate the costs and increase the benefits.

Decoupling Cash from Electronic Money, IMF WP 18/191 https://www.imf.org/ / media/Files/Publications/WP/2018/ wp18191.ashx and Agarwal and Kimball (2015) "Breaking Through the Zero Lower Bound," IMF WP 15/224 https://www.imf. org/en/Publications/WP/Issues/2016/12/31/ Breaking-Through-the-Zero-LowerBound-43358 


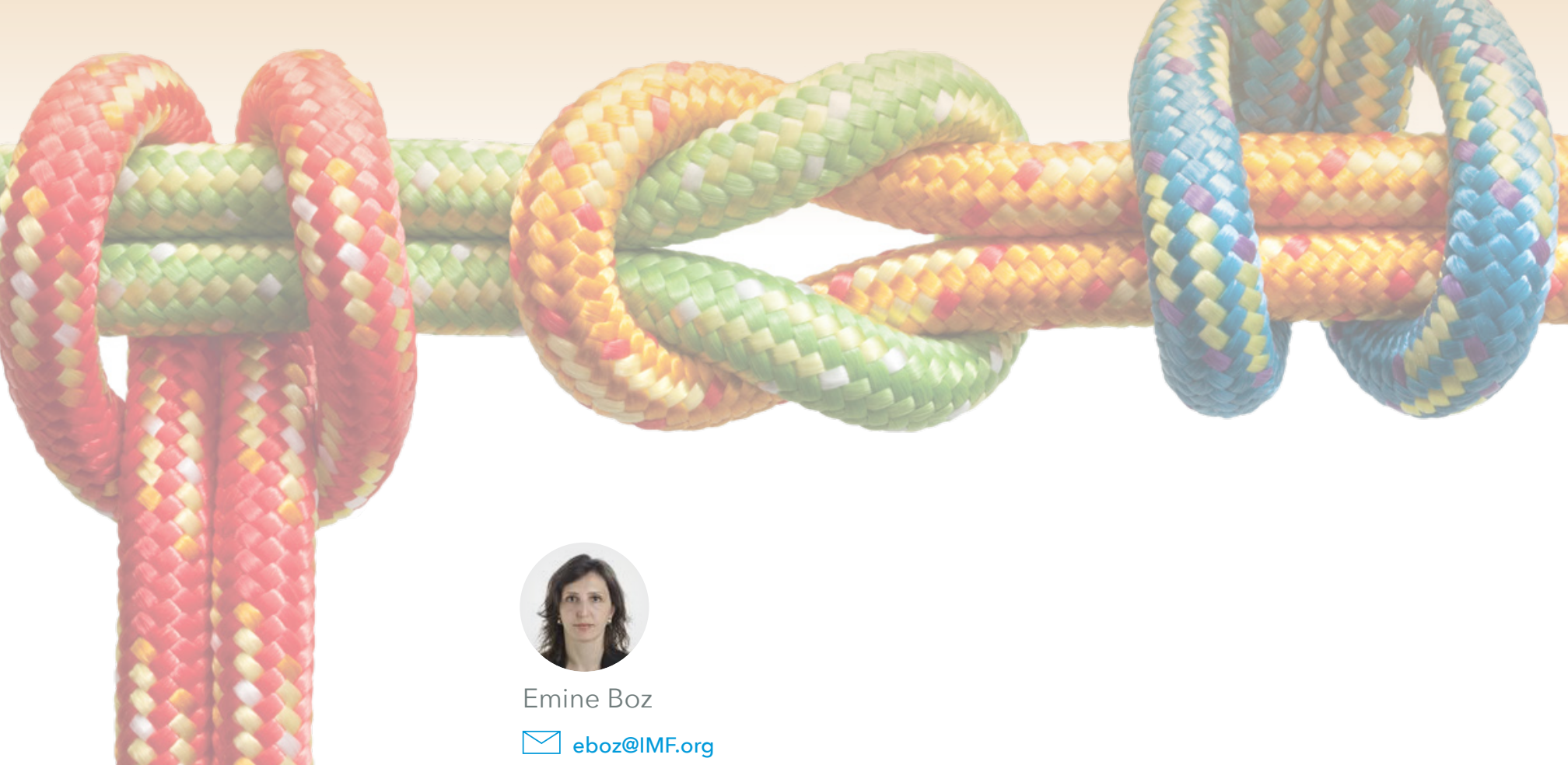

\section{ON THE ANNUAL RESEARCH CONFERENCE: A NOTE FROM THE ORGANIZER}

The Research Department held the 19th Jacques Polak Annual Research Conference on November 1-2, 2018. This year's conference brought together researchers and policymakers to discuss "International Spillovers and Cooperation," a timely topic given the potentially large cross-border spillovers but decreasing appetite for cooperation. Uncertainties about the size and direction of spillovers abound in all policy areas, so the conference featured six academic sessions covering a wide range of topics, including fiscal policy spillovers, design of implementable rules for international monetary policy coordination, and the consequences of trade protection in an increasingly interconnected world. The Mundell-Fleming lecturer, Raghu Rajan, focused on the spillovers from easy liquidity and its implications for multilateralism. A high-level policy panel comprising Agustin Carstens, Takatoshi Ito, Silvana Tenreyro, and Ksenia Yudaeva discussed the global implications of rising trade protectionism as rhetoric has increasingly turned into action, the role that multilateral institutions can play in facilitating international cooperation, and the policy challenges faced by emerging markets as monetary policy normalizes in large economies. 


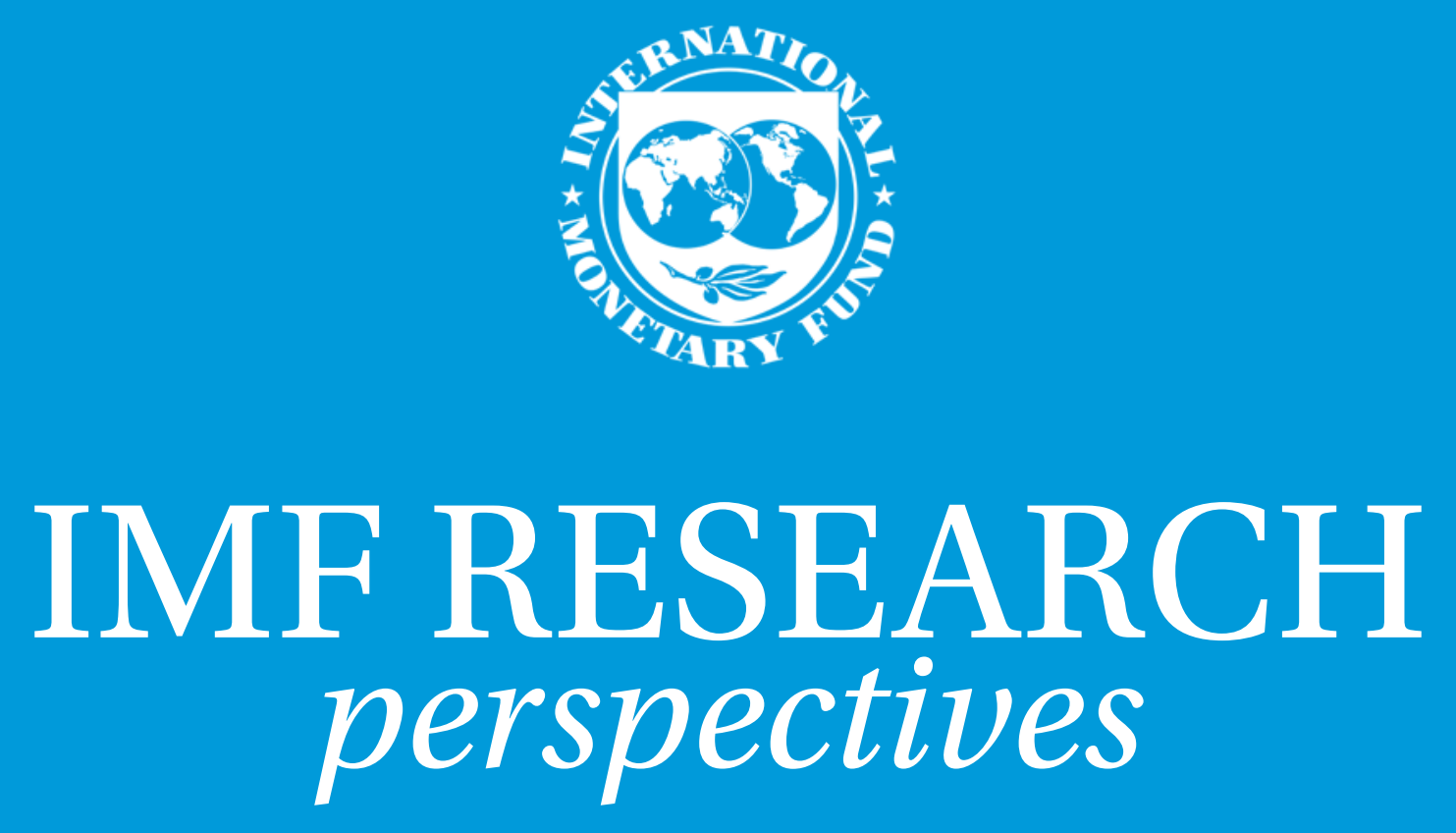

Learn more about IMF research at

IMF.org/external/research/

Visit IMF Economic Review, the official research journal of the IMF, at http://bit.ly/Palgrave-IMFER

Find IMF publications by visiting IMF.org/pubs

Preview selected titles at eLibrary.IMF.org/freepreview

\section{NEXT EDITION: JUNE 2019}

IMF.org/researchbulletin

CInternational Monetary Fund. Not for Redistribution 